\title{
Вплив експериментальної гострої крововтрати, ускладненої ішемією-реперфузією кінцівки, на діурез і швидкість клубочкової фі.льтрації
}

\begin{abstract}
Мета роботи: з’ясувати вплив гострої крововтрати, ускладненої ішемією-реперфузією кінцівки, на діурез і швидкість клубочкової фільтрації та оцінити ефективність карбацетаму в корекції виявлених порушень.

Матеріали і методи. Експерименти виконано на 96 нелінійних щурах-самцях масою 160-180 г. Усіх тварин поділили на п’ять груп: контрольну та чотири дослідних (по 6 щурів у групі). До першої дослідної групи увійшли тварини, яким під тіопенталнатрієвим наркозом моделювали двогодинну ішемію кінцівки з наступною реперфузією. У другій дослідній групі в умовах знеболення тваринам моделювали гостру крововтрату в обсязі 20-22 \% об’єму циркулюючої крові шляхом пересікання стегнової вени. У третій дослідній групі дані ушкодження поєднували. У четвертій дослідній групі тваринам з гострою крововтратою, ускладненою ішемією-реперфузією кінцівки, з метою корекції внутрішньоочеревинно вводили карбацетам (Інститут фізико-органічної хімії та вуглехімії НАН України, Донецьк) в дозі 5 мг на кілограм маси тварини. В контрольній групі тваринам вводили в наркоз, застосовуючи еквівалентну дозу тіопенталу натрію, накладали джгут на 2 год без припинення кровотоку і в подальшому брали для досліджень через одну годину.

Через 1 і 2 год, а також через 1, 7 і 14 діб у піддослідних тварин визначали функціональний стан нирок методом водного навантаження. Сечу збирали протягом 2 год і визначали діурез. Після забору сечі під тіопентал-натрієвим знеболенням щурів виводили з експерименту методом тотального кровопускання із серця. У сечі і сироватці крові визначали концентрацію креатиніну. Швидкість клубочкової фільтрації (ШКФ) оцінювали за кліренсом ендогенного креатиніну.

Результати досліджень та їх обговорення. Встановлено, що реперфузія після двогодинної ішемії супроводжується істотним порушенням функціонального стану нирок, що виявляється зниженням діурезу та ШКФ, величина яких до першої доби досягає мінімального рівня, проте до 14 доби - нормалізується. На тлі гострої крововтрати досліджувані показники знижувалися ще більше. У всі терміни спостереження діурез і ШКФ були статистично вірогідно меншими, ніж у тварин з ішемією-реперфузією кінцівки. За умов моделювання гострої крововтрати та ішемії-реперфузії кінцівки у всі терміни реперфузійного періоду величина діурезу виявилася істотно меншою, ніж за умов самої крововтрати. У свою чергу, ШКФ за цих умов статистично вірогідно знижувалася через 4 год і 7 діб реперфузійного періоду. Дослідження впливу карбацетаму показало, що його застосування в реперфузійному періоді вже через 7 діб привело до статистично значущого зростання діурезу та ШКФ у тварин 3 гострою крововтратою, ускладненою ішемією-реперфузією кінцівки. Ефект ставав ще більшим через 14 діб. Отже, карбацетам нівелює патогенні прояви гострої крововтрати та ішемії-реперфузії кінцівки і знижує прояви ниркової дисфункції, що свідчить про його перспективність як засобу системної корекції.
\end{abstract}

Ключові слова: крововтрата; ішемія-реперфузія кінцівки; нирка; діурез; швидкість клубочкової фільтрації.

Постановка проблеми і аналіз останніх досліджень та публікацій. Останніми десятиліттями в Україні, як і в усьому світі, спостерігається значне підвищення рівня тяжкості та летальності при травматичних ушкодженнях людини, що дозволяє стверджувати про “епідемію травматизму” $[6,10]$. В Україні проблема травматизму останнім часом набула особливої актуальності у зв'язку з тривалою антитерористичною операцією у східній частині країни [5].

3 огляду на той факт, що кровотеча є найвагомішою та найбільш грізною причиною смертельних наслідків поранень і травм, отриманих у цивільних умовах та при виконанні бойових операцій, використання турнікетів з метою порятунку життя постраждалих і поранених набуло значного поширення $[13,17]$. Однак, внаслідок різноманітних індивідуальних особливостей організму та певних об'єктивних перешкод щодо дотримання часових умов накладання джгута на поранену кінцівку [19], лікарям іноді доводиться мати справу 3 тяжкими, а іноді й смертельними ускладненнями травм при застосуванні турнікету [9, 15].

В експериментальних роботах ряду авторів показано, що двогодинна ішемія-реперфузія обох кінцівок внаслідок накладання джгутів як компонент поєднаної травми живота та гіповолемічного шоку поглиблює розвиток поліорганної дисфункції, зокрема порушення функціонального стану печінки та нирок $[8,14]$. Останнє вимагає всебічного дослідження ролі ішемії-реперфузії кінцівки в патогенезі поліорганної дисфункції, зумовленої гострою крововтратою. Недостатньо вивченим залишається системний вплив патогенних чинників гострої крововтрати та ішемії-реперфузії кінцівки на нирки, які є одними із основних органів-мішеней гострої гіпоксії та ендотоксинів з ішемізованих тканин $[12,16]$. За цих умов не встановлена 
ефективність карбацетаму, який, за даними авторів [4], проявляє антиоксидантну, імуномоделюючу, детоксикуючу, мембрано-стабілізуючу і тканинопротекторну дію.

Мета роботи: з'ясувати вплив гострої крововтрати, ускладненої ішемією-реперфузією кінцівки, на діурез і швидкість клубочкової фільтрації та оцінити ефективність карбацетаму в корекції виявлених порушень.

Матеріали і методи. Експерименти виконано на 96 нелінійних щурах-самцях масою 160-180 г з дотриманням правил “Європейської конвенції захисту хребетних тварин, яких використовують 3 експериментальною та іншою науковою метою” (European Convention, 1984).

Усіх тварин поділили на п'ять груп: контрольну та чотири дослідних (по 6 щурів у групі). До першої дослідної групи увійшли тварини, яким моделювали ішемію-реперфузію кінцівки. Під тіопентал-натрієвим знеболенням (40 мг.кг-1 маси тіла) тваринам проксимально на ліву лапку накладали джгут на 120 хв. Застосовували смужку еластичного джгута “SWAT-T” (США) шириною 10 мм, що відповідає ширині джгута при накладанні на стегно дорослій людині. Такий джгут характеризується мінімальним негативним впливом на прилеглі тканини за рахунок своєї ширини і тривалим в часі больовим порогом [18]. Джгут затягували відповідно до нанесеного на ньому індикатора ефективного тиску, який припиняє кровотік, що додатково було підтверджено реографічним методом. У другій дослідній групі в умовах знеболення тваринам моделювали гостру крововтрату шляхом пересікання стегнової вени. Після досягнення обсягу крововтрати 20-22 \% об'єму циркулюючої крові тваринам забезпечували гемостаз. У третій дослідній групі дані ушкодження поєднували. У четвертій дослідній групі тваринами 3 гострою крововтратою, ускладненою ішемією-реперфузією кінцівки, з метою корекції внутрішньоочеревинно вводили карбацетам (Інститут фізикоорганічної хімії та вуглехімії НАН України, Донецьк) в дозі 5 мг на кілограм маси тварини [4].

У контрольній групі тварин вводили в наркоз, застосовуючи еквівалентну дозу тіопенталу натрію, накладали джгут на 2 год без припинення кровотоку і в подальшому брали для досліджень через 1 год.

Через 1 і 2 години, а також через 1, 7 і 14 діб у піддослідних тварин визначали функціональний стан нирок методом водного навантаження [7]. Через металевий зонд у шлунок вводили підігріту до $30{ }^{\circ} \mathrm{C}$ водогінну воду в об’ємі 5 \% від маси ті- ла тварини. Сечу збирали протягом 2 год і визначали діурез. Після забору сечі під тіопентал-натрієвим знеболенням щурів виводили з експерименту методом тотального кровопускання із серця, що у ранній період експерименту відповідало 3 i 4 год реперфузії. У сечі і сироватці крові визначали концентрацію креатиніну уніфікованим методом для аналізатора біохімічного "Humalazer 2000”. Швидкість клубочкової фільтрації (ШКФ) оцінювали за кліренсом ендогенного креатиніну, яку розраховують за формулою:

ШКФ = Концентрації креатиніну в сечі $\times$ діурез / Концентрація креатиніну в плазмі.

Вірогідність відмінностей між контрольною і дослідними групами оцінювали з використанням непараметричного критерію Манна-Уїтні. Відмінності вважали істинними при вірогідності нульової гіпотези менше $5 \%(\mathrm{p}<0,05)$.

Результати досліджень та їх обговорення. За даними таблиці 1 , під впливом двогодинної ішемії величина діурезу, порівняно з контролем, поступово знижувалася й досягала мінімального рівня через одну добу реперфузійного періоду (на $14,5 \%, \mathrm{p}<0,05)$. В подальшому показник зростав і через 14 діб істотно не відрізнявся від контролю (p>0,05). Внаслідок гострої крововтрати діурез у всі терміни спостереження був суттєво меншим, ніж у контролі: через 3 год - на 33,0 \%, через 4 год - на 37,0 \%, через 1 добу - на 46,6 \%, через 7 діб - на 27,5 \%, через 14 діб - на 14,7 \% (p<0,05). В динаміці експерименту показник до першої доби реперфузії знижувався, що виявилися статистично значущим, порівняно $з$ попередніми термінами спостереження $(\mathrm{p}<0,05)$. В подальшому показник зростав, що через 14 діб виявилося статистично вірогідним порівняно з усіма попередніми термінами спостереження $(\mathrm{p}<0,05)$. Ускладнення гострої крововтрати ішемією-реперфузією супроводжувалося ще більшим зниженням величини діурезу порівняно з контролем: через 3 год - на $40,8 \%$, через 4 год - на 45,8 \%, через одну добу на 54,6 \%, через 7 діб - на 45,1 \%, через 14 діб - на $27,0 \%(\mathrm{p}<0,05)$.

Порівняння дослідних груп між собою показало, що у всі терміни спостереження у дослідній групі 1 величина діурезу виявилася істотно більшою, ніж у дослідних групах 2 і $3\left(\mathrm{p}_{1-2}<0,05\right.$, $\left.\mathrm{p}_{1-3}<0,05\right)$. Порівняння дослідних груп 2 і 3 показало, що ускладнення гострої крововтрати ішемією-реперфузією кінцівки в усі терміни спостереження супроводжувалося істотним зниженням величини діурезу, порівняно з групою, в якій моделювали гостру крововтрату: через 3 год - на 
Таблиця 1. Діурез (мкл·хв ${ }^{-1} \cdot 100 \mathrm{r}^{-1}$ ) після гострої крововтрати, ускладненої ішемією-реперфузією кінцівки (Me (LQ;UQ)) - медіана (нижній і верхній квартилі ((Me (LQ;UQ) - медіана (нижній і верхній квартилі))

\begin{tabular}{|c|c|c|c|c|c|}
\hline \multirow{2}{*}{ Дослідна група } & \multicolumn{5}{|c|}{ Термін реперфузійного періоду } \\
\hline & 3 год & 4 год & 1 доба & 7 доба & 14 доба \\
\hline \multicolumn{6}{|c|}{ Контроль = 36,75 $(36,39 ; 37,47)(\mathrm{n}=6)$} \\
\hline $\begin{array}{l}\text { Група } 1 \\
\text { Ішемія-реперфузія }\end{array}$ & $\begin{array}{l}35,21^{*} \\
(34,51 ; \\
37,12) \\
(n=6)\end{array}$ & $\begin{array}{c}34,61^{*} \\
(33,09 ; \\
36,13) \\
(n=6)\end{array}$ & $\begin{array}{c}31,43^{* 3 r, 4 r} \\
(31,06 ; \\
31,08) \\
(n=6)\end{array}$ & $\begin{array}{c}33,82^{*{ }_{1}} \\
(32,55 ; \\
35,72) \\
(n=6)\end{array}$ & $\begin{array}{c}37,92^{4 \mathrm{r}, 1 д, 7 д} \\
(37,47 ; \\
38,20) \\
(\mathrm{n}=6)\end{array}$ \\
\hline $\begin{array}{l}\text { Група } 2 \\
\text { Крововтрата }\end{array}$ & $\begin{array}{l}24,62^{*} \\
(23,92 ; \\
26,84) \\
(n=6)\end{array}$ & $\begin{array}{c}23,14^{*} \\
(22,93 ; 23,76) \\
(n=6)\end{array}$ & $\begin{array}{c}21,88 * 3 г, 4 г \\
20,86 ; \\
21,48) \\
(n=6)\end{array}$ & $\begin{array}{c}26,66^{* 45,} \\
(25,56 ; \\
27,03) \\
(\mathrm{n}=6)\end{array}$ & $\begin{array}{c}31,34^{* 3 r, 4 r, 1,7 д} \\
(30,69 ; \\
32,13) \\
(\mathrm{n}=6)\end{array}$ \\
\hline $\begin{array}{l}\text { Група } 3 \\
\text { Ішемія- } \\
\text { реперфузія+ } \\
\text { крововтрата }\end{array}$ & $\begin{array}{l}21,76^{*} \\
(21,04 ; \\
22,98) \\
(n=6)\end{array}$ & $\begin{array}{l}20,65^{*} \\
(19,93 ; \\
21,50) \\
(n=6)\end{array}$ & $\begin{array}{c}16,67^{* 3,45} \\
(16,17 ; \\
19,13) \\
(n=6)\end{array}$ & $\begin{array}{l}20,16^{* 1 \text { म }} \\
(19,07 ; \\
21,71) \\
(\mathrm{n}=6)\end{array}$ & $\begin{array}{c}26,81^{* 3 r, 4 r, 1,7 д} \\
(26,20 ; \\
27,19) \\
(n=6)\end{array}$ \\
\hline $\mathrm{p}_{1-2}$ & $<0,05$ & $<0,05$ & $<0,05$ & $<0,05$ & $<0,05$ \\
\hline $\mathrm{p}_{1-3}$ & $<0,05$ & $<0,05$ & $<0,05$ & $<0,05$ & $<0,05$ \\
\hline $\mathrm{P}_{2-3}$ & $<0,05$ & $<0,05$ & $<0,05$ & $<0,05$ & $<0,05$ \\
\hline
\end{tabular}

Примітки. Тут і в табл. 2:

1) ${ }^{\text {- }}$ відмінності стосовно контрольної групи статистично вірогідні $(\mathrm{p}<0,05)$;

2) $\mathrm{p}_{1-2}$ - вірогідність відмінностей між дослідними групами 1 і 2;

3) $\mathrm{p}_{1-3}$ - вірогідність відмінностей між дослідними групами 1 і 2;

4) $\mathrm{p}_{23}$ - вірогідність відмінностей між дослідними групами 1 і 3 ;

5) ${ }^{3 r, 4 r, 1,7 д}$ - відмінності стосовно відповідно 3 і 4 год, а також 1 і 7 діб експерименту статистично вірогідні $(p<0,05)$.

11,6 \%, через 4 год - на 10,8 \%, через 1 добу - на 20,9 \%, через 7 діб - на 24,4 \%, через 14 діб - на $14,4 \%\left(\mathrm{p}_{2-3}<0,05\right)$.

У свою чергу, швидкість клубочкової фільтрації (табл. 2) під впливом ішемії-реперфузії (дослідна група 1) порівняно з контролем зменшувалася вже через 3 год реперфузійного періоду (на $24,0 \%, \mathrm{p}<0,05)$. Показник продовжував знижуватися до 1 доби й ставав істотно меншим, порівняно 3 попередніми термінами спостереження $(\mathrm{p}<0,05)$ та порівняно з контролем (на 39,6 \%, p<0,05). У подальшому показник зростав і до 14 доби нормалізувався $(\mathrm{p}>0,05)$. Під впливом гострої крововтрати швидкість клубочкової фільтрації була істотно нижчою від контролю протягом усього терміну спостереження: через 3 год - на 45,0 \%, через 4 год - на 48,5 \%, через 1 добу - на 68,0 \%, через 7 діб - на 57,1 \%, через 14 діб - на 50,0 \% (p<0,05). В динаміці показник до 1 доби знижувався, що було статистично значущим порівняно з попередніми термінами спостереження $(\mathrm{p}<0,05)$. Далі показник зростав і через 14 діб на 56,3 \% був більшим, ніж через 1 добу $(\mathrm{p}<0,05)$, проте не досягав рівня контролю. Гостра крововтрата, ускладнена ішемієюреперфузією, порівняно з контролем, супроводжувалася ще більшим зниженням швидкості клубочкової фільтрації: через 3 год - на 50,7 \%, через 4 год - на 61,5 \%, через 1 добу - на 73,9 \%, через 7 діб на 69,6 \%, через 14 діб - на 61,6 \% (p<0,05).

Порівнюючи дослідні групи між собою, встановили, що у всі терміни спостереження у дослідній групі 1 величина діурезу виявилася істотно більшою, ніж у дослідних групах 2 і $3\left(\mathrm{p}_{1-2}<0,05, \mathrm{p}_{1-3}<0,05\right)$. Порівняння дослідних груп 2 і 3 показало, що за умов ускладнення гострої крововтрати ішемією-реперфузією кінцівки показник через 4 год і 7 діб був статистично вірогідно меншим, ніж у групі з гострою крововтратою (відповідно на 25,3 і 29,1 \%, $\left.\mathrm{p}_{2-3}<0,05\right)$. В інші терміни показник між цими групами статистично вірогідно не відрізнявся $\left(\mathrm{p}_{2-3}>0,05\right)$.

Аналізуючи ефективність застосування карбацетаму, ми встановили, що під впливом карбацетаму величина діурезу (рис. 1), порівняно з тваринами без корекції, через 7 і 14 діб була статис- 
Таблиця 2. Швидкість клубочкової фрільтрації (мкл·хв ${ }^{-1} \cdot 100 r^{-1}$ ) після гострої крововтрати, ускладненої ішемією-реперфузією кінцівки (Me (LQ;UQ)) - медіана (нижній і верхній квартилі)

\begin{tabular}{|c|c|c|c|c|c|}
\hline \multirow[t]{2}{*}{ Дослідна група } & \multicolumn{5}{|c|}{ Термін реперфузійного періоду } \\
\hline & З год & 4 год & 1 доба & 7 доба & 14 доба \\
\hline \multicolumn{6}{|c|}{ Контроль = 426,8 (411,1; 453,3) $(n=6)$} \\
\hline $\begin{array}{l}\text { Група } 1 \\
\text { Ішемія-реперфузія }\end{array}$ & $\begin{array}{c}367,2^{*} \\
(347,2 ; \\
399,0) \\
(n=6)\end{array}$ & $\begin{array}{c}362,8^{*} \\
(351,7 ; \\
371,9) \\
(n=6)\end{array}$ & $\begin{array}{c}257,9^{* 3 r, 4 r} \\
(245,9 ; \\
267,6) \\
(n=6)\end{array}$ & $\begin{array}{c}316,4^{* 1 д} \\
(293,7 ; \\
367,8) \\
(n=6)\end{array}$ & $\begin{array}{c}422,3^{4 г, 1 д, 7 \text { म }} \\
(403,2 ; \\
448,0) \\
(n=6)\end{array}$ \\
\hline $\begin{array}{l}\text { Група } 2 \\
\text { Крововтрата }\end{array}$ & $\begin{array}{c}234,8^{*} \\
(221,3 ; \\
260,9) \\
(n=6)\end{array}$ & $\begin{array}{c}219,8^{*} \\
(190,7 ; \\
235,3) \\
(n=6)\end{array}$ & $\begin{array}{c}136,4^{* 3 \mathrm{r}, 4 \Gamma} \\
(134,9 ; \\
150,1) \\
(n=6)\end{array}$ & $\begin{array}{c}183,1^{* 3 г, 4 г, 1 д} \\
(167,2 ; \\
197,7) \\
(n=6)\end{array}$ & $\begin{array}{c}213,2^{* 1 д} \\
(179,3 ; \\
263,3) \\
(n=6)\end{array}$ \\
\hline $\begin{array}{l}\text { Група } 3 \\
\text { Ішемія-реперфузія+ } \\
\text { крововтрата }\end{array}$ & $\begin{array}{l}210,5 * \\
(192,6 ; \\
217,3) \\
(n=6)\end{array}$ & $\begin{array}{l}164,1^{* 1 \Gamma} \\
(158,7 ; \\
166,3) \\
(n=6)\end{array}$ & $\begin{array}{c}111,6^{* 3 \Gamma, 4 \Gamma} \\
(104,2 ; \\
125,0) \\
(n=6)\end{array}$ & $\begin{array}{c}129,9^{* 3 г, 4 г} \\
(123,7 ; \\
142,3) \\
(n=6)\end{array}$ & $\begin{array}{c}163,7^{* 3 г, 1 д, 7 д} \\
(144,1 ; \\
185,8) \\
(n=6)\end{array}$ \\
\hline $\mathrm{p}_{1-2}$ & $<0,05$ & $<0,05$ & $<0,05$ & $<0,05$ & $<0,05$ \\
\hline $\mathrm{p}_{1-3}$ & $<0,05$ & $<0,05$ & $<0,05$ & $<0,05$ & $<0,05$ \\
\hline $\mathrm{p}_{2-3}$ & $>0,05$ & $<0,05$ & $>0,05$ & $<0,05$ & $>0,05$ \\
\hline
\end{tabular}

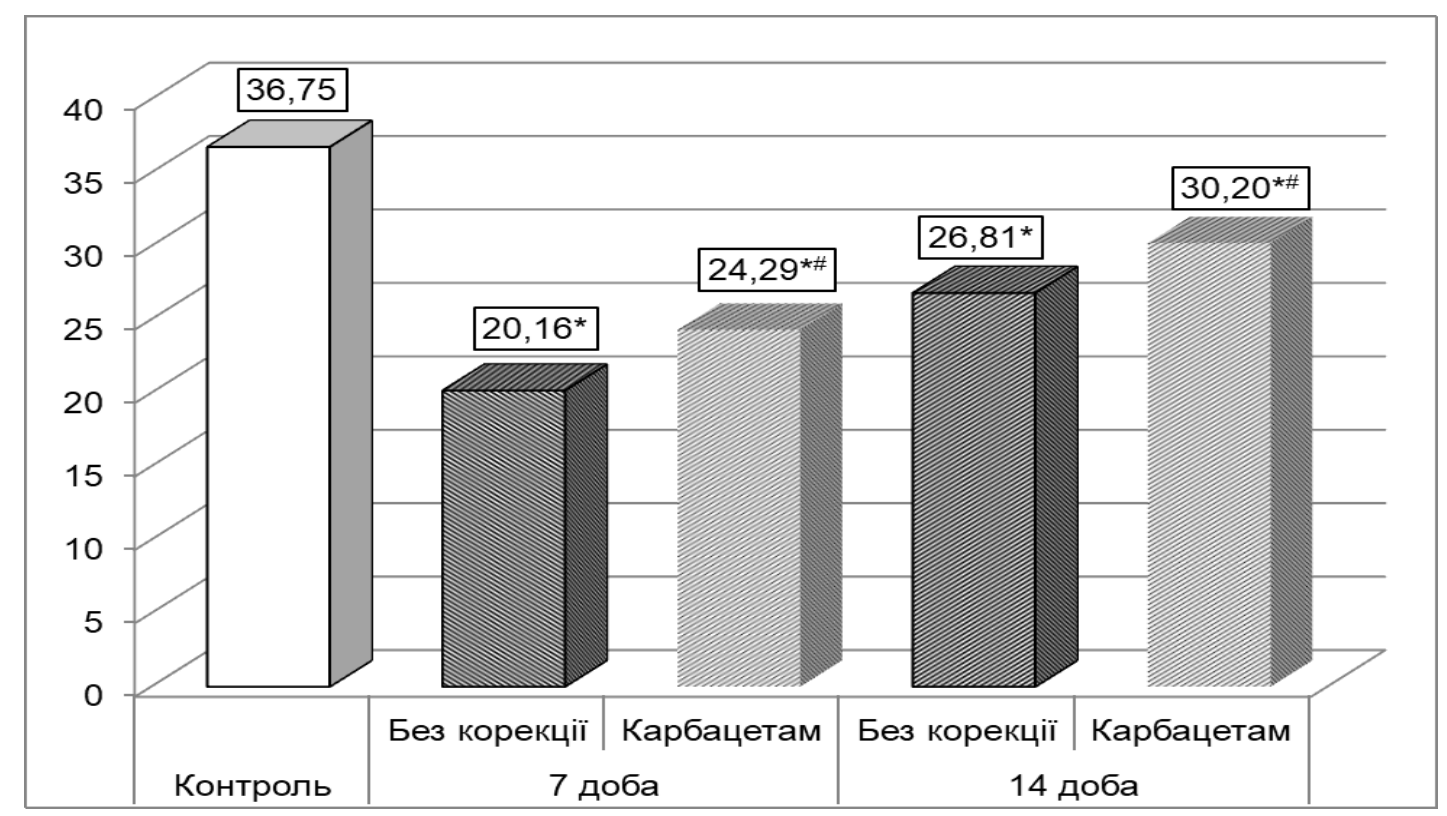

Рис. 1. Вплив карбацетаму на діурез (мкл·хв $\left.{ }^{-1} \cdot 100 \Gamma^{-1}\right)$ після гострої крововтрати, ускладненої ішемією-реперфузією кінцівки. (Примітка. Тут і на рис. 2: * відмінності стосовно контрольної групи статистично вірогідні, p<0,05; \# - відмінності стосовно групи без корекції статистично вірогідні, p<0,05).

тично вірогідно більшою (відповідно, на 20,5 і $12,6 \%, \mathrm{p}<0,05)$. Аналогічно більшою внаслідок застосування карбацетаму стала й ШКФ (рис. 2): відповідно, на 54,3 і у 2,07 раза ( $<<0,05)$.
Отримані результати свідчать про те, що реперфузія після двогодинної ішемії супроводжується істотним порушенням функціонального стану нирок, що виявляється зниженням діурезу та 


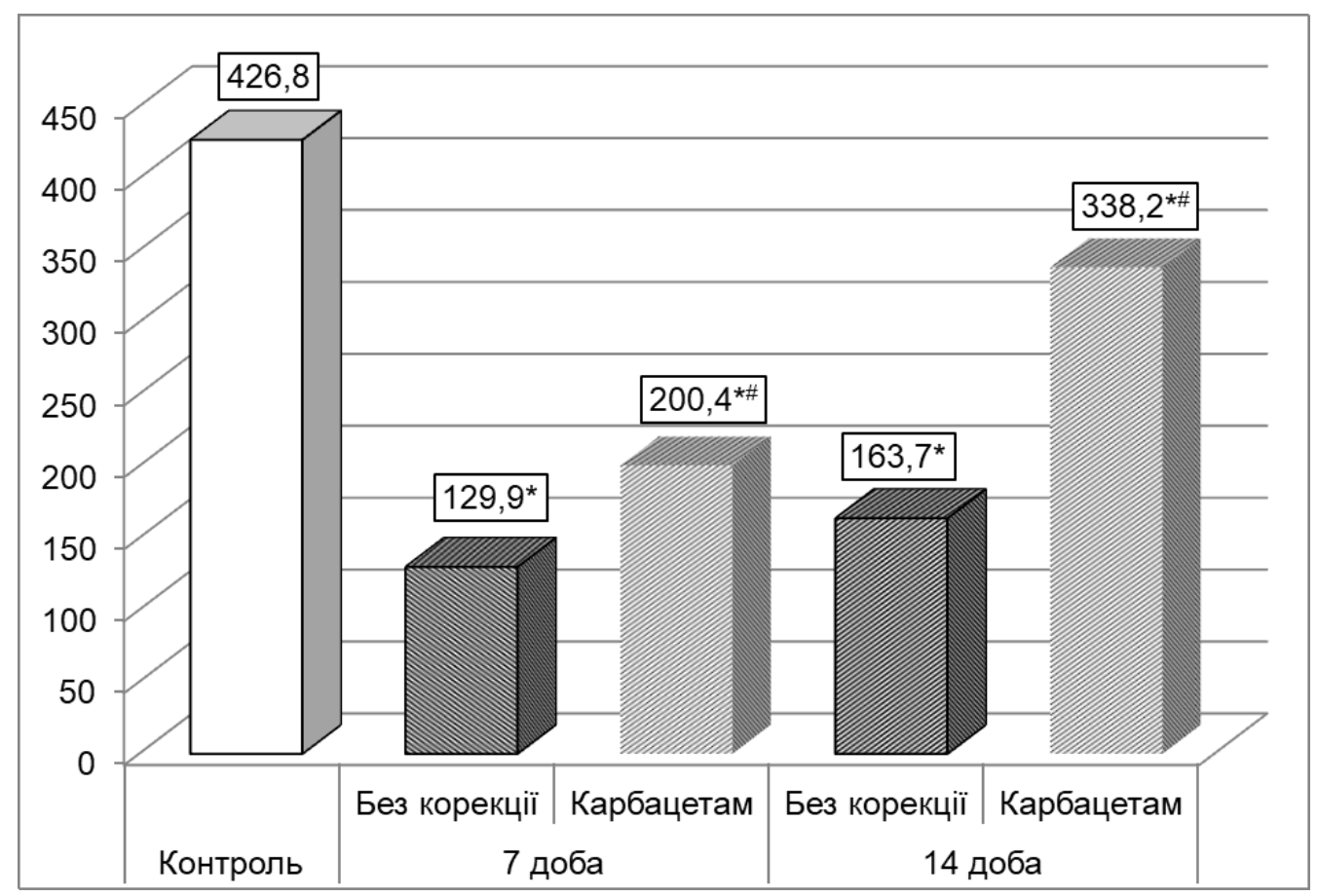

Рис. 2. Вплив карбацетаму на ШКФ (мкл·хв $\left.{ }^{-1} \cdot 100 \Gamma^{-1}\right)$ після гострої крововтрати, ускладненої ішемією-реперфузією кінцівки.

ШКФ, величина яких до 1 доби досягає мінімального рівня, проте до 14 доби - нормалізується. Це вказує на те, що патогенні фактори, які надходять у кров з ішемізованої кінцівки, зумовлюють тривале порушення фільтраційно-реабсорбційної здатності нирок. Відомо, що відновлення кровообігу в кінцівці призводить до масивного надходженню до системного кровообігу продуктів анаеробного метаболізму, вільного міоглобіну, біологічно активних речовин і медіаторів запалення $[1,11]$. Можна припустити, що саме ці чинники $\epsilon$ провідними у вторинному ураженні нирок при ішемії-реперфузії кінцівки. Це припущення підтверджують дані окремих авторів, які встановили істотне підвищення показників ліпідної пероксидації в сироватці крові після двогодинної ішемії та реперфузії кінцівки, що вказує на виражені системні порушення, зумовлені прооксидантними чинниками, які надходять 3 реперфузованої кінцівки і активують каскад вторинних реакцій в органах і тканинах організму [2]. Проте до 14 доби досліджувані показник досягають рівня контрольної групи. Отже, відхилення в організмі внаслідок двогодинної ішемії з наступною реперфузією знаходяться в межах гомеостатичного регулювання організму, проте $\epsilon$ тривалими в часі.

У свою чергу, на тлі гострої крововтрати досліджувані показники знижувалися ще більше. У всі терміни спостереження діурез і ШКФ бу- ли статистично вірогідно меншими, ніж у тварин з ішемією-реперфузією кінцівки. Отримані дані $є$ свідченням типової реакції нирок на гостру крововтрату, зокрема на зниження перфузії [3]. Проте за умов моделювання гострої крововтрати та ішеміїреперфузії кінцівки у всі терміни реперфузійного періоду величина діурезу виявилася істотно меншою, ніж за умов крововтрати. У свою чергу, ШКФ за цих умов статистично вірогідно знижувалася через 4 год і 7 діб реперфузійного періоду. Отримані результати дозволяють припустити, що внаслідок впливу гострої крововтрати та ішемії-реперфузії кінцівки має місце сумація їх негативного впливу на організм, зокрема на функціональний стан нирок. Останнє має вагоме значення для клініки, оскільки факт ішемії і реперфузії кінцівки може бути вагомим чинником тяжкості перебігу основної патології, яким часто нехтують. Все це одночасно вимагає розробки адекватних засобів корекції. Дослідження впливу карбацетаму показало, що його застосування у реперфузійному періоді вже через 7 діб привело до статистично значущого зростання діурезу та ШКФ у тварин з гострою крововтратою, ускладненою ішемією-реперфузією кінцівки. Ефект ставав ще більшим через 14 діб. Отже, карбацетам нівелює патогенні прояви гострої крововтрати та ішемії реперфузії кінцівки і знижує прояви ниркової дисфункції, що свідчить про його перспективність як засобу системної корекції. 
Висновки. 1. Двогодинна ішемія кінцівки у реперфузійному періоду супроводжується істотним зниженням діурезу та ШКФ, які досягають мінімальної величини через 1 добу і повертаються до рівня контролю через 14 діб.

2. Після моделювання гострої крововтрати амплітуда порушень діурезу та ШКФ у всі терміни спостереження стає статистично вірогідно більшою, ніж за умов ішемії-реперфузії, проте їх динаміка залишається подібною з максимальним зниженням через добу та підвищенням - через 14 діб, яке не досягає рівня контролю.

\section{СПИСОК ЛІТЕРАТУРИ}

1. Абдоминальный сепсис и окислительный стресс / И. Н. Пасечник, Е. И. Скобелев, В. В. Крылов [и др.] // Хирургия. Журнал им. Н. И. Пирогова. - 2015. - № 12. - С.18-23.

2. Біохімічні зміни у сироватці крові щурів при ішемічно-реперфузійному синдромі (експериментальне дослідження) / А. А. Телев’як, Т. О. Вересюк, П. Р. Сельський, І. І. Боймиструк // Здобутки клінічної і експериментальної медицини. 2018. - № 2 (34). - С. 122-128.

3. Ковальов В. В. Динаміка функціонального стану нирок у ранній період після нанесення скелетної травми різної тяжкості, ускладненої крововтратою / В. В. Ковальов, Д. В. Попович // Вісник наукових досліджень. - 2018. - № 4. - С. 184189.

4. Козак Д. В. Вплив карбацетаму на антиоксидантний-прооксидантний баланс тканини серця, легень і печінки в динаміці політравми / Д. В. Козак // Шпитальна хірургія. - 2014. № 1 (65). - С. 40-42.

5. Король С. О. Статистична характеристика вогнепальних та мінно-вибухових поранень стегна, отриманих під час проведення антитерористичної операції / С. О. Король, Б. В. Матвійчук, В. М. Коваленко // Хірургія України. - 2017. - Т. 61, № 1. - C. 18-22.

6. Логистика и медицинское обеспечение межгоспитальной транспортировки пострадавших с политравмой при чрезвычайных ситуациях в системе службы медицины катастроф Украины / Д. А. Трошин, И. В. Кочин, А. А. Гайволя [и др.] // Медицина неотложных состояний. - 2014. - Т. 62, № 7. - С. 174-175.

7. Роговий Ю. Є. Патофізіологія гепаторенального синдрому на поліуричній стадії сулемової нефропатії / Ю. Є. Роговий. Чернівці : “Місто”, 2012. - 200 с.

8. Цимбалюк Г. Ю. Стан добового діурезу нирок в умовах ішемічно-реперфузійного синдрому кінцівок, травми органів черевної порожнини, ускладненої гіповолемічним шоком, та їх поєднання у ранньому періоді травматичної хвороби / Г. Ю. Цимбалюк // Здобутки клінічної та експериментальної медицини. - 2018. - Вип. 3 (35). - С. 163-169.

9. Cunningham L. A survey of upper and lower limb tourniquet use among Irish orthopaedic surgeons / L. Cunningham,
3. Ускладнення гострої крововтрати ішемієюреперфузією кінцівки супроводжується сумацією їх негативного впливу на функціональний стан нирок. За цих умов у всі терміни спостереження величина діурезу статистично вірогідно менша порівняно з дослідною групою, в якій моделювали саму гостру крововтрату, ШКФ - через 4 год та 7 діб.

4. Застосування карбацетаму тваринам 3 гострою крововтратою та ішемією-реперфузією кінцівки супроводжується вираженим позитивним ефектом і зумовлює підвищення діурезу та ШКФ через 7 діб реперфузійного періоду. Ефект поглиблюється через 14 діб.

T. McCarthy, J. O’Byrne // Ir. J. Med. Sci. - 2013. - Vol. 182, No. 3. - P. 325-330.

10. GBD 2016 Mortality Collaborators. Global, regional, and national under-5 mortality, adult mortality, age-specific mortality, and life expectancy, 1970-2016 / H. Wang, A. A. Abajobir, K. H. Abate [et al.] // Lancet. - 2017. - Vol. 390 (10100). P. $1084-1150$.

11. Heat-shock proteins and acute ischaemic kidney injury / S. O'Neill, E. M. Harrison, J. A. Ross [et al.] // Nephron Experim ental Nephrology. - 2014. - Vol. 126, No. 4. - P.167-174.

12. Hydrogen sulphide and the kidney: important roles in renal physiology and pathogenesis and treatment of kidney injury and disease / I. Lobb, E. Sonke, G. Aboalsamh, A. Sener // Nitric Oxide. - 2015. - Vol. 46. - P. 55-65.

13. Kotwal R. S. Junctional hemorrhage control for tactical combat casualty care / R. S. Kotwal, F. K. Butler Jr. // Wilderness Environ. Med. - 2017. - Vol. 28, No. 2. - P. 33-38.

14. Kuzminskyi I. V. Bile production features in case of ischemicreperfusion syndrome of limbs, abdominal trauma complicated with massive blood loss / I. V. Kuzminskyi, V. O. Krylyuk, M. A. Maksymenko // Journal of Education, Health and Sport, formerly Journal of Health Sciences. - 2018. - Vol 8, No. 10. - P. 209-218.

15. Martini W. Z. Coagulation complications following trauma / W. Z. Martini // Mil. Med. Res. - 2016. - Vol. 22, No. 3. - P. 35. 16. Role of hydrogen sulfide in ischemia-reperfusion injury / D. Wu, J. Wang, H. Li [et al.] // Oxid. Med. Cell Longev. - 2015. - Vol. 1. - P. 1-16.

17. Survival with emergency tourniquet use to stop bleeding in major limb trauma / J. F. Jr. Kragh, T. J. Walters, D. G. Baer [et al.] // Ann. Surg. - 2009. - Vol. 249. - P. 1-7.

18. Tourniquets and occlusion: the pressure of design / P. L. Wall, D. C. Duevel, M. B. Hassan [et al.] // Mil. Med. 2013. - Vol. 178 (5). - P. 578-587.

19. Volotovska N. V. Changes in the glutathione system's activity of internal organs in the first hours of experimental limb ischemiareperfusion syndrome, combined with blood loss and mechanical injury / N. V. Volotovska, T. C. Nhokwara, I. V. Zhulkevych // Здобутки клінічної і експериментальної медицини. - 2019. № 1. - C. 23-27. DOI 10.11603/1811-2471.2019.v0.i1.10043 


\section{REFERENCES}

1. Pasechnik, I.N., Skobelev, E.Y., Krylov, V.V., Salnykov, P.S., Vershynina, M.H., Blokhina, N.V., \& Meshcheryakov, A.A. (2015). Abdomynalnyy sepsys i okislitelnyy stress [Abdominal sepsis and oxidative stress]. Khirurgiya. Zhurnal im. N.I. Pirogova - Surgery. Journal by N.I. Pirogov, 12, 18-23 [in Russian].

2. Televiak, A.A., Veresiuk, T.O., Selskyi, P.R., \& Boimystruk, I.I. (2018). Biokhimichni zminy u syrovattsi krovi shchuriv pry ishemichno-reperfuziinomu syndromi (eksperymentalne doslidzhennia) [Biochemical changes in blood serum of rats with reperfusion-ischemic syndrome (experimental study)]. Zdobutky klinichnoi i eksperymentalnoi medytsyny Achievements of Clinical and Experimental Medicine, 2 (34), 122-128 [in Ukrainian].

3. Kovalov, V.V., \& Popovych, D.V. (2018). Dynamika funktsionalnoho stanu nyrok u rannii period pislia nanesennia skeletnoi travmy riznoi tiazhkosti, uskladnenoi krovovtratoiu [Dynamics of functional condition of kidneys in the early period after skeletal injury of different severe complicated by blood loss]. Visnyk naukovykh doslidzhen - Bulletin of Scientific Research, 4, 184-189 [in Ukrainian].

4. Kozak, D.V. (2014). Vplyv karbatsetamu na antyoksydantnyiprooksydantnyi balans tkanyny sertsia, lehen $\mathrm{i}$ pechinky $\mathrm{v}$ dynamitsi politravmy [Influence of carbacetam on antioxidantprooxidant balance of tissue of heart, lungs and liver in the dynamics of polytrauma]. Shpytalna khirurhiia - Hospital Surgery, 1 (65), 40-42 [in Ukrainian].

5. Korol, S.O., Matviichuk, B.V., \& Kovalenko, V.M. (2017). Statystychna kharakterystyka vohnepalnykh ta minnovybukhovykh poranen stehna, otrymanykh pid chas provedennia antyterorystychnoi operatsii [Statistical characteristics of gunshot and blast injuries of the thigh, obtained during the anti-terrorist operation]. Khirurhiia Ukrainy - Surgery of Ukraine, 61, 1, 1822 [in Ukrainian].

6. Troshyn, D.A., Kochyn, Y.V., Hayvolya, A.A., Akulova, O.M., \& Shylo, Y.F. (2014). Logistika i meditsynskoe obespechenye mezhgospitalnoy transportirovky postradavshykh s politravmoy pri chrezvychaynykh situatsyyakh v sisteme sluzhby meditsyny katastrof Ukrayiny [Logistics and medical support of inter-hospital transportation of victims with polytrauma in emergency situations in the catastrophe medicine service of Ukraine]. Medytsyna neotlozhnykh sostoyaniy - Emergency Medicine, 62, 7, 174-175 [in Russian].

7. Rohovyi, Yu.Ye. (2012). Patofiziolohiia hepatorenalnoho syndromu na poliurychnii stadii sulemovoi nefropatii [Pathophysiology of hepatorenal syndrome at the polyuric stage of sulemic nephropathy]. Chernivtsi: Misto [in Ukrainian].

8. Tsymbaliuk, H.Yu. (2018). Stan dobovoho diurezu nyrok $\mathrm{v}$ umovakh ishemichno-reperfuziinoho syndromu kintsivok. Travmy orhaniv cherevnoi porozhnyny, uskladnenoi hipovolemichnym shokom, ta yikh poiednannia u rannomu periodi travmatychnoi khvoroby [Condition of diurnal diuresis of the kidneys in conditions of ischemic-reperfusion limb syndrome. injuries of abdominal organs complicated by hypovolemic shock and their combination in the early period of traumatic disease]. Zdobutky klinichnoi i eksperymentalnoi medytsyny Achievements of Clinical and Experimental Medicine, 3 (35), 163-169 [in Ukrainian].

9. Cunningham, L., McCarthy, T., \& O’Byrne, J. (2013). A survey of upper and lower limb tourniquet use among Irish orthopaedic surgeons. Ir. J. Med. Sci., 182, 3, 325-330.

10. Wang, H., Abajobir, A.A., Abate, K.H., Abbafati, C., Abbas, K.M., Abd-Allah, F., ..., \& Murray, C.J.L. (2017). GBD 2016 Mortality Collaborators. Global, regional, and national under-5 mortality, adult mortality, age-specific mortality, and life expectancy, 1970-2016. Lancet, 390 (10100), 1084-1150.

11. O'Neill, S., Harrison, E.M., Ross, J.A., Wigmore, S.J., \& Hughes, J. (2014). Heat-Shock Proteins and Acute Ischaemic Kidney Injury. Nephron Experimental Nephrology, 126, 4, 167174.

12. Lobb, I., Sonke, E., Aboalsamh, G., \& Sener, A. (2015). Hydrogen sulphide and the kidney: important roles in renal physiology and pathogenesis and treatment of kidney injury and disease. Nitric Oxide, 46, 55-65.

13. Kotwal, R.S., \& Butler, F.K.Jr. (2017). Junctional hemorrhage control for tactical combat casualty care. Wilderness Environ. Med., 28, 2, 33-38.

14. Kuzminskyi, I.V., Krylyuk, V.O., \& Maksymenko, M.A. (2018). Bile production features in case of ischemic-reperfusion syndrome of limbs, abdominal trauma complicated with massive blood loss. Journal of Education, Health and Sport, formerly Journal of Health Sciences, 8, 10, 209-218.

15. Martini, W.Z. (2016). Coagulation complications following trauma. Mil. Med. Res., 22, 3, 35.

16. Wu, D., Wang, J., Li, H., Xue, M., Ji, A., \& Li, Y. (2015).

Role of hydrogen sulfide in ischemia-reperfusion injury. Oxid. Med. Cell Longev, 1, 1-16.

17. Kragh, J.F.Jr., Walters, T.J., Baer, D.G., Fox, C.J., Wade, C.E., Salinas, J., \& Holcomb, J.B. (2009). Survival with emergency tourniquet use to stop bleeding in major limb trauma. Ann. Surg., 249, 1-7.

18. Wall, P.L., Duevel, D.C., Hassan, M.B., Welander, J.D., Sahr, S.M., \& Buising, C.M. (2013). Tourniquets and occlusion: the pressure of design. Mil Med., 178 (5), 578-587.

19. Volotovska, N.V., Nhokwara, T.C., \& Zhulkevych, I.V. (2019). Changes in the glutathione system's activity of internal organs in the first hours of experimental limb ischemiareperfusion syndrome, combined with blood loss and mechanical injury. Zdobutky klinichnoi i eksperymentalnoi medytsyny Achievements of Clinical and Experimental Medicine, 1, 23-27. DOI 10.11603/1811-2471.2019.v0.i1.10043 
V. V. SHATSKY, A. A. HUDYMA, R. V. BLYZNIUK

I. Horbachevsky Ternopil National Medical University

\title{
INFLUENCE OF EXPERIMENTAL ACUTE BLOOD LOSS COMPLICATED BY ISCHEMIA-REPERFUSION OF THE EXTREMITY ON THE SIZE OF DIURESIS AND THE GLOMERULAR FILTRATION RATE
}

\begin{abstract}
The aim of the work: to find out the effect of acute blood loss complicated by limb ischemia-reperfusion on diuresis and glomerular filtration rate and to evaluate the effectiveness of carbacetam in correcting the revealed violations.

Materials and Methods. The experiments were performed on 96 non-linear male rats weighing 160-180 g. All animals were divided into five groups: control and four experimental (6 rats per group). The first experimental group included animals, which under thiopental-sodium anesthesia simulated a two-hour limb ischemia followed by reperfusion. In the second experimental group, in conditions of animal anesthesia, acute blood loss was simulated in the amount of 20-22\% of the circulating blood volume by crossing the femoral vein. In the third experimental group, these injuries were combined. In the fourth experimental group of animals with acute blood loss complicated by limb ischemia-reperfusion, carbacetam (Institute of Physico-Organic Chemistry and Coal Chemistry of the National Academy of Sciences of Ukraine, Donetsk) was administered intraperitoneally in a dose of $5 \mathrm{mg}$ per kilogram of animal weight. In the control group, animals were injected into anesthesia using an equivalent dose of thiopental sodium, a tourniquet was applied for 2 hours without stopping the blood flow, and subsequently taken for studies after 1 hour.

After 1 and 2 hours, as well as after 1, 7 and 14 days in the experimental animals, the functional state of the kidneys was determined by the method of water loading. Urine was collected over 2 hours and diuresis was determined. After urine sampling in thiopental sodium anesthesia, rats were removed from the experiment by total bloodletting from the heart. In urine and blood serum, creatinine concentration was determined. Glomerular filtration rate (GFR) was evaluated by the clearance of endogenous creatinine.

Results and Discussion. It was established that reperfusion after two hours of ischemia is accompanied by a significant impairment of the functional state of the kidneys, which is manifested by a decrease in urine output and GFR, the value of which reaches a minimum level by 1 day, but normalizes by 14 days. Against the background of acute blood loss, the studied parameters decreased even more. At all observation times, diuresis and GFR were statistically significantly less than in animals with limb ischemia-reperfusion. Under the conditions of modeling acute blood loss and limb ischemia-reperfusion during all periods of the reperfusion period, the amount of diuresis was significantly less than with blood loss itself. In turn, GFR under these conditions statistically significantly decreased after 2 hours and 7 days of the reperfusion period. A study of the effect of carbacetam showed that its use in the reperfusion period after 7 days led to a statistically significant increase in diuresis and GFR in animals with acute blood loss complicated by ischemia-reperfusion of the limb. The effect became even greater after 14 days. Thus, carbacetam eliminates the pathogenic manifestations of acute blood loss and limb ischemia-reperfusion and reduces the manifestations of renal dysfunction, which indicates its promise as a means of systemic correction.
\end{abstract}

Key words: blood loss; ischemia-reperfusion of the limb; kidney; diuresis; glomerular filtration rate.

\author{
В. В. ШАЦКИЙ, А. А. ГУДИМА, Р. В. БЛИЗНЮК
}

Тернопольский национальный медицинский университет имени И. Я. Горбачевского МОЗ Украины

\section{В.ЛИЯНИЕ ЭКСПЕРИМЕНТАЛЬНОЙ ОСТРОЙ КРОВОПОТЕРИ, ОС.ОЖНЕННОЙ ИНЕМИЕЙ- РЕПЕРФУЗИЕЮ КОНЕЧНОСТИ, НА ДИУРЕЗ И СКОРОСТЬ КЛУБОЧКОВОЙ ФИЛЬТРАЦИИ}

Цель работы: выяснить влияние острой кровопотери, осложненной ишемией-реперфузиею конечности, на диурез и скорость клубочковой фильтрации и оценить эффективность карбацетама в коррекции выявленных нарушений.

Материалы и методы. Эксперименты выполнены на 96 нелинейных крысах-самцах массой 160-180 г. Всех животных разделили на пять груп: контрольную и четыре опытных (по 6 крыс в группе). В первую опытную группу вошли животные, которым под тиопентал-натриевым наркозом моделировали двухчасовую ишемию конечности с последующей реперфузией. Во второй опытной группе в условиях обезболивания животных моделировали острую кровопотерю в объеме 20-22 \% объема циркулирующей крови путем пересечения бедренной вены. В третьей опытной группе эти повреждения сочетали. В четвертой опытной группе животных с острой кровопотерей, осложненной ишемией-реперфузией конечности, с целью коррекции внутрибрюшинно вводили карбацетам (Институт физико-органической химии и углехимии НАН Украины, Донецк) в дозе 5 мг на килограмм массы животного. В контрольной группе животных вводили в наркоз, применяя эквивалентную дозу тиопентала натрия, накладывали жгут на 2 ч без прекращения кровотока и в дальнейшем брали для исследований через один час.

Через 1 и 2 ч, а также через 1, 7 и 14 суток у подопытных животных определяли функциональное состояние почек методом водной нагрузки. Мочу собирали в течение 2 ч и определяли диурез. После забора мочи под тиопентал-натриевым обезболиванием крыс выводили из эксперимента методом тотального кровопускания из сердца. В моче и сыворотке крови определяли концентрацию креатинина. Скорость клубочковой фильтрации (СКФ) оценивали по клиренсу эндогенного креатинина.

Результаты исследований и их обсуждение. Установлено, что реперфузия после двухчасовой ишемии сопровождается существенным нарушением функционального состояния почек, что проявляется снижением диуреза и СКФ, величина которых к первым суткам достигает минимального уровня, однако к 14 суток - нормализируется. На фоне острой кровопотери иссле- 


\section{ЕКСПЕРИМЕНТАЛЬНІ ДОСЛІДЖЕННЯ}

дуемые показатели снижались еще больше. Во все сроки наблюдения диурез и СКФ были статистически достоверно меньше, чем у животных с ишемией-реперфузией конечности. В условиях моделирования острой кровопотери и ишемии-реперфузии конечности во все сроки реперфузионного периода величина диуреза оказалась существенно меньше, чем при самой кровопотере. В свою очередь, СКФ в этих условиях статистически достоверно снижалась через 4 часа и 7 дней реперфузионного периода. Исследование влияния карбацетама показало, что его применение в реперфузионном периоде уже через 7 суток привело к статистически значимому росту диуреза и СКФ у животных с острой кровопотерей, осложненной ишемией-реперфузией конечности. Эффект становился еще больше через 14 дней. Таким образом, карбацетам нивелирует патогенные проявления острой кровопотери и ишемии-реперфузии конечности и снижает проявления почечной дисфункции, что свидетельствует о его перспективности как средства системной коррекции.

Ключевые слова: кровопотеря; ишемия-реперфузия конечности; почка; диурез; скорость клубочковой фильтрации. 